\title{
Engineering Assessment of Low-Level Liquid Waste Disposal Caisson Locations at the 618-11 Burial Grounds
}

Prepared for the U.S. Department of Energy Office of Environmental Restoration and Waste Management

\section{(2) Westinghouse \\ Hanford Company Richland, Washington}

Hanford Operations and Engineering Contractor for the

U.S. Department of Energy under Contract DE-AC06-87RL10930

Approved for Pıblic Release 
WHC-MR-0400

UC-70

\section{Engineering Assessment of Low-Level Liquid Waste Disposal Caisson Locations at the 618-11 Burial Grounds}

S. J. Phillips

D. D. Fischer

R. C. Crawford

Westinghouse Hanford Company

\section{J. L. Rising}

Pacific Northwest Laboratory

Date Published

June 1982

Prepared for the U.S. Department of Energy Office of Environmental Restoration and Waste Management

\footnotetext{
(2.) Westinghouse Hanford Company Richland, Washington 99352

Hanford Operations and Engineering Contractor for the

U.S. Department of Energy under Contract DE-AC06-87RL10930
}

Approved for Public Release 


\section{LEGAL DISCLAIMER}

This report was prepared as an account of work sponsored by an agency of the United States Government. Neithar the

Uniled States Government nor any agency thereof, nor any of their employees, nor any of their contractors, subcontractors or their employees, makes any warranty, express or implied. or assumes any legal liability or responsibility lor the accuracy, completeness, or any third party's use or the results of such use of any information, apparatus, product, or process disclosed, or represents that its use would not infringe privately owned rights. Reference herein to any specific commercial product, process, or service by trade name, trademark, manufacturer, or otherwise, does not necessarily constitute or imply its endorsement, recommendation, or favoring by the United States Government or any agency thereof or its contractors or subcontractors. The views and opinions of authors expressed herein do not necessarily state or reflect those of the United States Government or any agency thereof.

This report has been reproduced from the best available copy. Available in paper copy and microfiche.

Available to the U.S. Department of Energy

and its contractors from

Office of Scientific and Technical Information

P.0. Box 62

Oak Ridge, TN 37831

(615) 576.840

Availabie to the public from the U.S. Department of Commerce National Technical Iniormation Service

5285 Port Royal Road

Springlield, VA 22161

(703) $487-4650$

Printed in the United States of America

DISCLM-1.CHP $(1.81)$ 
PRELIMINARY TOPICAL REPORT

ENGINEERING ASSESSMENT OF LOW-LEVEL LIQUID WASTE

DISPOSAL CAISSON LOCATIONS AT THE 618-11 BURIAL GROUNDS

PREFARED BY:

S. J. Phillips (1)

D. D. Fischer (1)

J. L. Rising (2)

R. C. Crawford (3)

JUNE 1982

(1) Rockwell Hanford Operations: Research and Engineering

(2) Pacific Northwest Laboratory: Water and Land Resources

(3) Rockwell Hanford Operations: Health, Safety and Environment 


\section{WHC-MR-0400}

ABSTRACT

Low-level waste disposal caissons were used in 300 Area (618-10 and 618-11) Burial Grounds as internment structures for containerized liquid wastes. These caissons, by virtue of theircontents, design and methods of closure, require long-term performance evaluation. As an initial activity to evaluate long-term performance, the accurate location of these structures is required. This topical report summarizes engineering activities used to locate caissons in the subsurface environment at the 618-11 Burial Ground. Activities were conducted to locate caissons during surface stabilization activities.

Vertically off-set large volume caissons and vertical moderate volume caissons were accurately located in the northeast quadrant of the burial ground. The surface locations were marked, photographed, and recorded on an as built engineering drawing.

The recorded location of these caissions will augment long-term observations of confinement structure and engineered surface barrier performance. In addition, accurate caisson location will minimize occupational risk during monitoring and observation activities periodically conducted at the burial ground. 
Rockwell Hanford Operations, under the direction of the Department of Energy, Richland Operations Office, is currently involved in an extensive effort to perform interim ground surface stabilization activities at retired low-level waste burial grounds located at the Hanford Site, Richland, Washington. The burial ground on which this evaluation is focused is located 15 $\mathrm{km}$ north-northeast of the Hanford 300 Area. The burial ground is directly adjacent to the Washington Public Power Supply System (WPPSS) \#2 Reactor site (Figure 1). The principal objective of these activities is to promote increased occupational and radiological safety at burial grounds. Interim stabilization activities include: (1) load testing (traversing burial ground surfaces with heavy equipment to promote ircipient collapse of void spaces within the disposal structure and overburden), (2) barrier placement (placement of $a \geqslant 0.6 \mathrm{~m}$ soil. barrier over existing overburden), and (3) revegetation (establishment of shallow rooted vegetation on the barrier to mitigate deep rooted plant growth and to reduce erosion).

Interim surface stabilization of burial grounds has proven effective for enhancing the overburden stability of most low-level waste disposal sites where applied. However, surface stabilization activities are not intended to promote physical stability of buried waste forms. Physical instability of buried waste caissons over time may result in collapse of the overburden (cave-in or similar surface manifestations) covering the disposal structure and may ultimately result in occupational or public exposure. Cave-ins in the 618-11 Burial Ground have been reported by occupational workers.

Caissons in the 618-11 Burial Ground have been located previously by referencing an engirieering as built drawing (H-2-930). The accuracy of this drawing is questionable in that recordkeeping during the operational period of the burial ground was less than optimum. Surface maintenance activities over the last number of years since termination of operations has also changed the surface morphology of the burial ground. Current interim surface stabilization activities additionally have changed the surface morphology and increased 
N

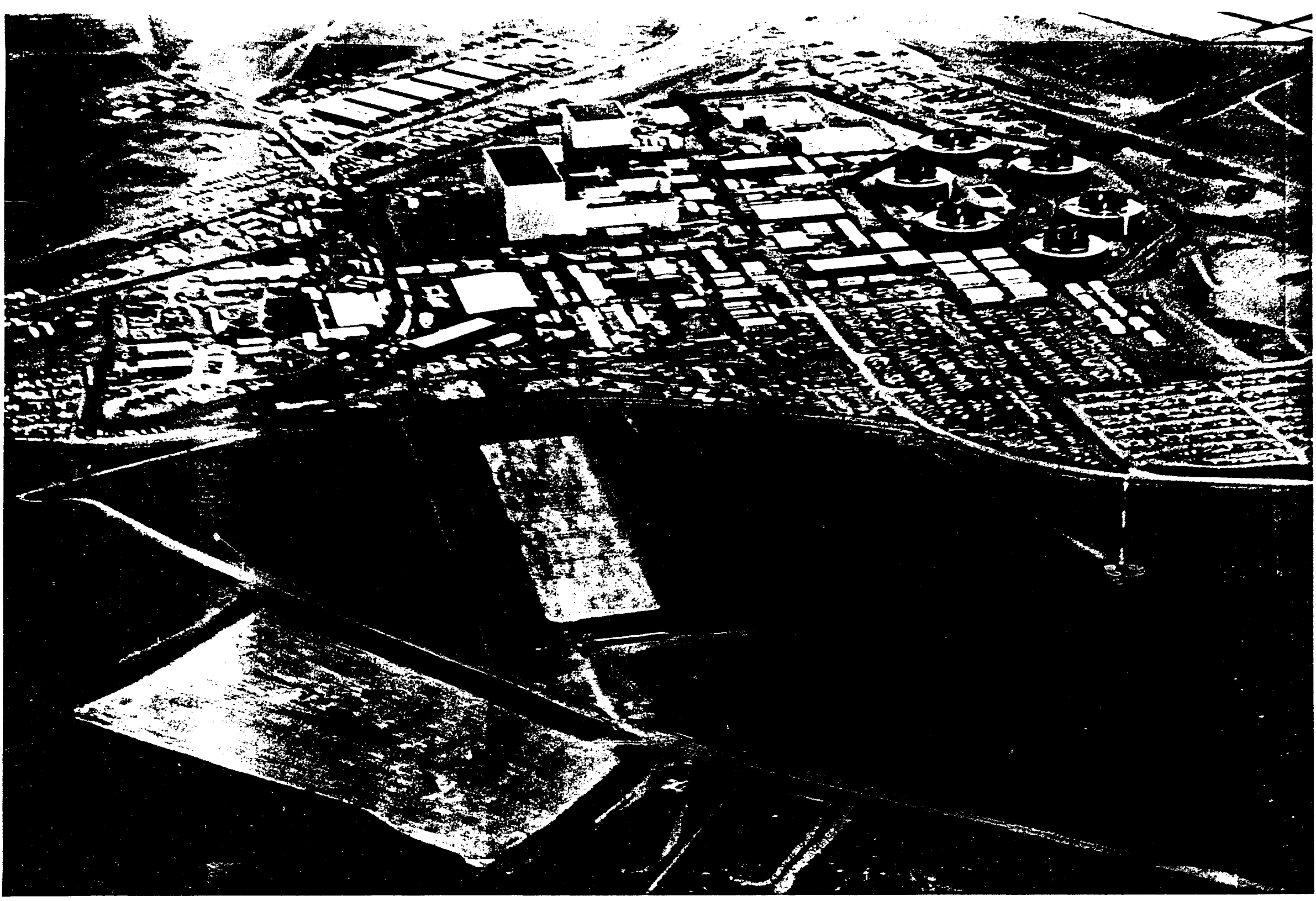


the burial depth thus further limiting the accuracy of caisson location.

After burial ground overburden emplacement in May of 1982 at the 618-11 Burial Ground, locations of buried caissons in the northeast quadrant of the burial ground were determined. The locations were marked, photographed, and referenced to the engineering as-built drawing. The location of these caissons with respect to evaluating the performance of current surface stabilization activities is required. This summary topical report delineates buried caisson locations which are reauired for baseline information used to assess burial ground surface stabilization activities.

METHODS AND MATERIALS

A portable inductance radio frequency (RF) transceiver (coupled transmitter and receiver) was chosen to locate buried metal caissons (Phillips, et. al., 1980). Utilizing as-built detail "A" and "B", (drawing attached to back cover) it was determined that the caissons in this burial ground were constructed of steel drums or corrugated metal pipe. The transceiver operates on the induction balance, or transmit-receive principle, i.e., one transmitter loop coil and one receiver loop coil are geometrically arranged in such a way that a null or zero-induction condition is obtained in the absence of nearby metallic objects. When the coils are properly adjusted, the receiver is insensitive to the electromagnetic field of the transmitter. A signal is detected if the electromagnetic field at the receiver coil is altered by the superposition of a secondary electromagnetic field resulting from induced currents in a nearby metallic object or conductive mass. Deviations from the balance condition are detected as electrical signals in the receiver and are electronically converted to a meter deflection as well as an audible tone. The transceiver was field calibrated by operating in an area of known buried metal targets of various morphology and depth. Calibration checks were also completed by determining instrument sensitivity by transmitting and receiving RF signal over known horizontal distances.

The transceiver was operated in the northeast quadrant of the 618-11 Burial Ground. The transceiver was passed over the ground surface at a height of approximate $0.5 \mathrm{~m}$. Traverses were made over an established grid. 
WHC-MR-0400

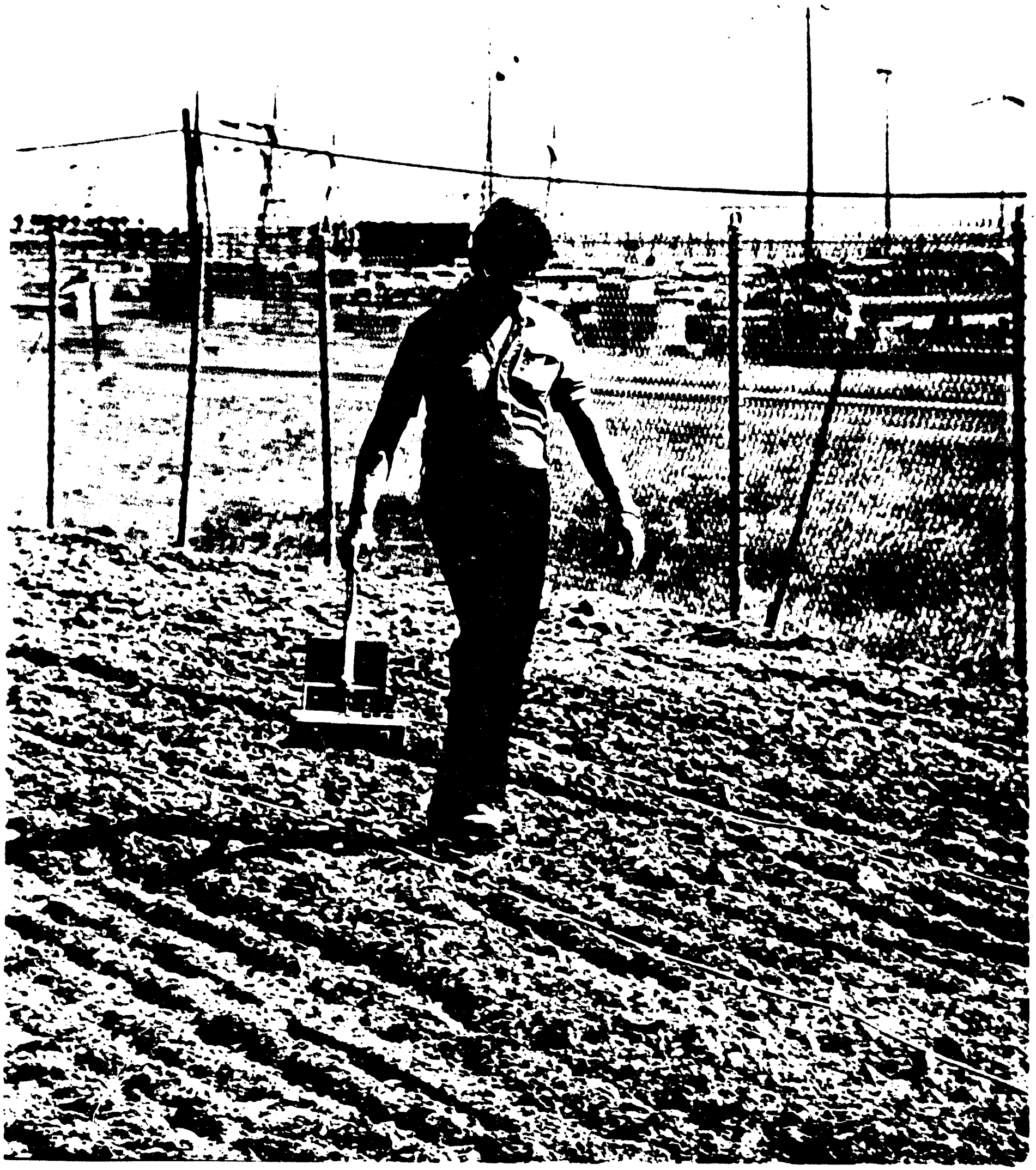

FIGURE 2: OPERATIONAL MODE OF TRANSVERSING BURIAL GROUND WITH TRANSCEIVER TO LOCATE CAISSONS. 
The grid was configured by alternately placing nylon rope at $1.5 \mathrm{~m}$ intervals laterally across the quadrant from existing concrete burial ground markers. The grid was oriented normal to the north-south burial ground boundary marker configuration. Continuous traverses were made laterally over the quadrant at a lateral spacing of $0.75 \mathrm{~m}$. Traverses proceeded from east-west markers to a distance of approximately $30 \mathrm{~m}$ toward the cènter of the burial ground.

Once the transceiver detected a subsurface metallic target, the transceiver was passed across the center of the target horizontally at approximately $45^{\circ}$ radial increments. This accurately determined the center of the target and the relative lateral extent. Thus, large volume caissons and small volume targets were distinguished. The center of each target was marked at grade with a metal post. The lateral distance from the target center where the signal was no longer received was also marked. Hence, the center and lateral circumference of each caisson was marked. Figure 2 shows the operational. mode of traversing the burial ground with a transceiver used to locate caissons.

On completion of marking each subsurface target, aerial targets were placed within the southwest quadrant of the burial ground. These aerial targets were used to match as built engineering drawings to photographs of the burial ground. Burial targets of small volume caissons consisted of 0.58 by $0.40 \mathrm{~m}$ ruled paper placed on the ground surface over a marker post. Aerial targets used to mark large volume caissons consisted of the same ruled paper and additionally six 0.15 by $0.37 \mathrm{~m}$ paper fragments arranged at the lateral circumference of the subsurface target. At the corners of the quadrant and at each concrete burial ground marker, 0.37 by $0.37 \mathrm{~m}$ paper fragment aerial markers were also installed.

Photographs of subsurface target markers and the total burial ground were taken. Photo enlargement transparencies of the as built drawing were made from the original drawing. These transparencies were then overlayed on enlarged aerial photographs. Corresponding caisson location and descrepancies in location were then marked on the photograph (Figure 3). 
An as-built Hanford drawing issued in 1979 (H-6-930) entitled "Plot Plan 618-11 Wye Burial Ground" identifies the burial ground location and configuration of waste confinement structures and their general location in trenches throughout the burial ground (Appendix I). The drawing depicts a 1:100 scale "base" plan view and a 1:50 scale enlargement of the northern half. Caissons are located in the northeast and north sections of the base and enlarged plan views, respectively. Three linear arrays of caissons are delineated on each of the base and enlarged views; the base view shows 21,26 and 10 unit caisson arrays oriented roughly east-west. The enlarged view shows 20,26 and 10 unit arrays of the same configuration. One additional caisson in the base view extending westward from the 2-68-27 Burial Ground marker is shown which is not delineated on the enlarged view. The distance between caissons is nominally equivalent in the base and enlarged plan views.

Photographs of caisson locations as determined by the field survey, however, show discrepancies in addition to that shown between the base and enlarged as-built drawing. The northern most array was found to contain 23 caissons, three of which the drawing omits. The western section of the center arraywas found to contain 14 caissons as opposed to the 16 depicted in the drawing. The field survey shows 12 small volume caissons and 2 large volume caissons. The as-built drawing does distinguish between large and small volume caissons in this part of the center array, but the spacing of caissons in the center array western section differs between the as-built drawing and the engineering surveys. The drawing shows; 10 eveniy spaced low volume caissons $(22 \mathrm{~m}$. diameter) east to west, 3 evenly spaced medium (24-36 in. diameter caissons further to the west $(\sim 9 \mathrm{~m})$, and 2 large volume caissons (96 in. diameter) located $\sim 30 \mathrm{~m}$ further to the west. The photograph shows over the same general interval, 6 evenly spaced low volume caissons, 2 sets of low volume caissons and 3 large volume caissons. The general locations, type and spacing of the southern array caissons are consistent between the as-built orawing and the survey. 


\section{WHC-MR-0400}

Figure 3 shows the original as-built diagram caisson locations indicated with black circles and squares on an aerial photograph. The discrepancies between the two are marked by arrows.

The transceiver also detected buried metalic waste in a trench adjacent to the southernmost caisson array. This material was not marked on the photographs. It was clearly demonstrated that trench locations can be determined with limited accuracy using the transceiver.

\section{CONCLUSIONS}

This topical report summarizes activities conducted during May 1982 to accurately determine the locations of buried caissons located in the 618-11 Burial Ground. This report further outlines the method and instrumentation used to determine buried metal caissons. The methods and instrumentation is consistent with typical engineering activities to detect buried metallic materials, i.e., civil engineering, foundation engineering and construction/maintenance activities. Accurate, inexpensive, hence cost effective location of burial caissons was demonstrated. The cost of the $618-11$ engineering survey was less then $\$ 2,300$. Survey cost per unit survey area over complete burial grounds, e.g., the 618.10 (300 North Burial Ground) is expected to cost less than the above, as procedures were refined and optimized on Burial Ground 618-11.

Engineering surveys of burial grounds and other waste management and chemical processing subsurface facilities may be successfully completed using the method applied to the 618-11 Burial Ground. These engineering surveys may be completed as a precursor to surface stabilization and or other decontamination/decommissioning activities in order to determine the location of buried waste forms and trenches containing metallic waste. These surveys may also be used to augment location of waste transfer piping, etc.

As well as proving the principle of this engineering survey technique other benefits were also realized. The results from this survey can be 
$\boldsymbol{\infty}$

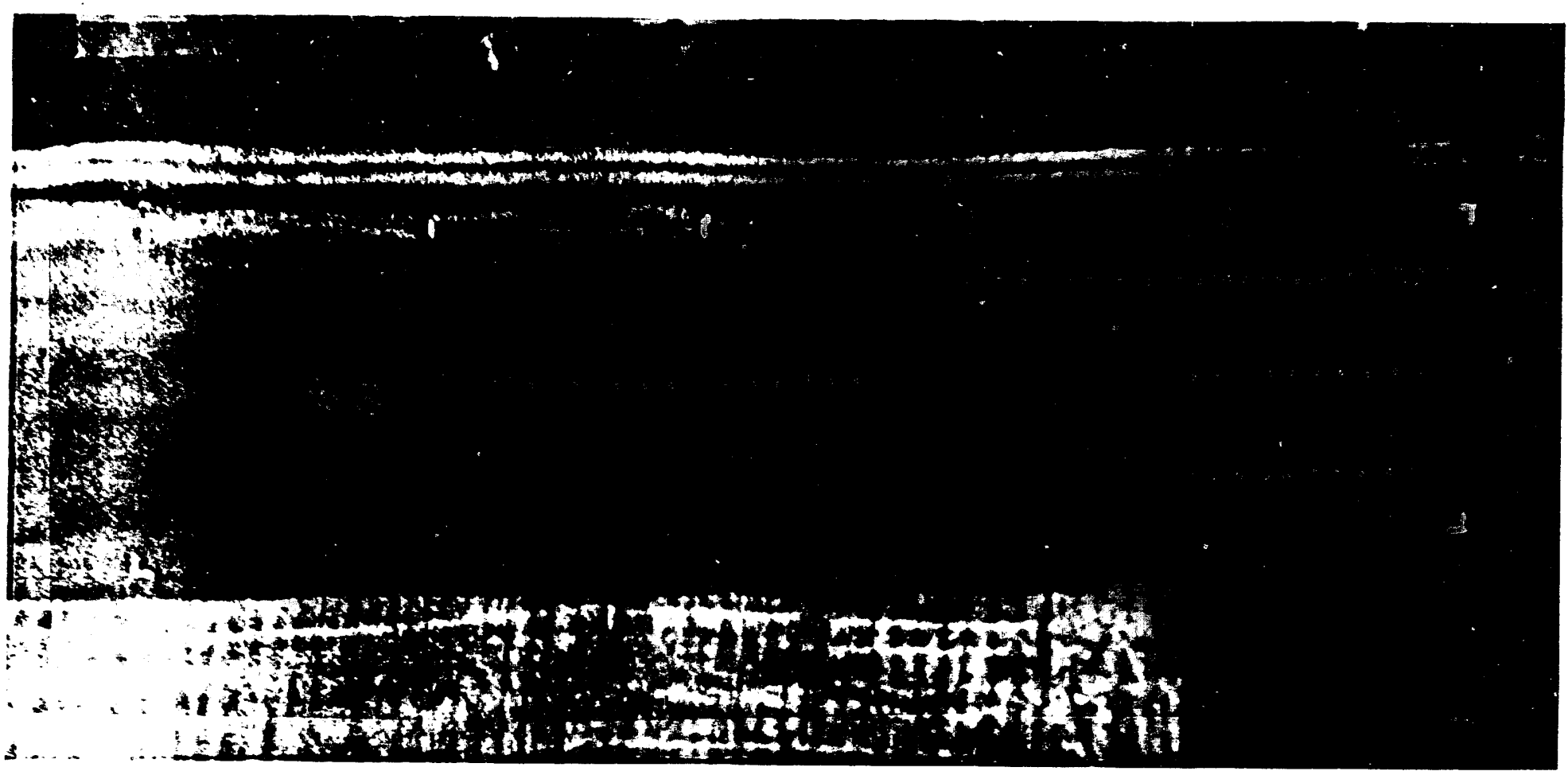

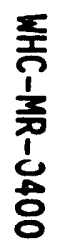

FIGURE 3: AS-BUILT DIAGRAM CAISSON LOCATION INDICATED ON AERIAL PHOTOGRAPH OF 618-11 BURIAL GROUND. ARROWS MARK DISCREPANCIES. 


\section{WHC-MR-0400}

utilized to correct the as-built drawing. The up-to-date drawings can be used with confidence in the future. This assessment is a positive step towards better burial ground characterization.

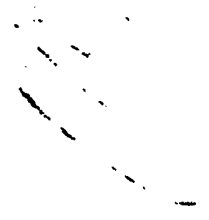


Phillips, S. J., L. L. Ames, R. F. Fitzner, - G.W. Gee, G. A. Sandness and C. S. Simmon, 1980, "Characterization of the Hanford 300 Area Burial Grounds: Final Report - Decontamination and Decomissioning", Pacific Northwest Laboratory, PNL-2557, Richland, Washington. 


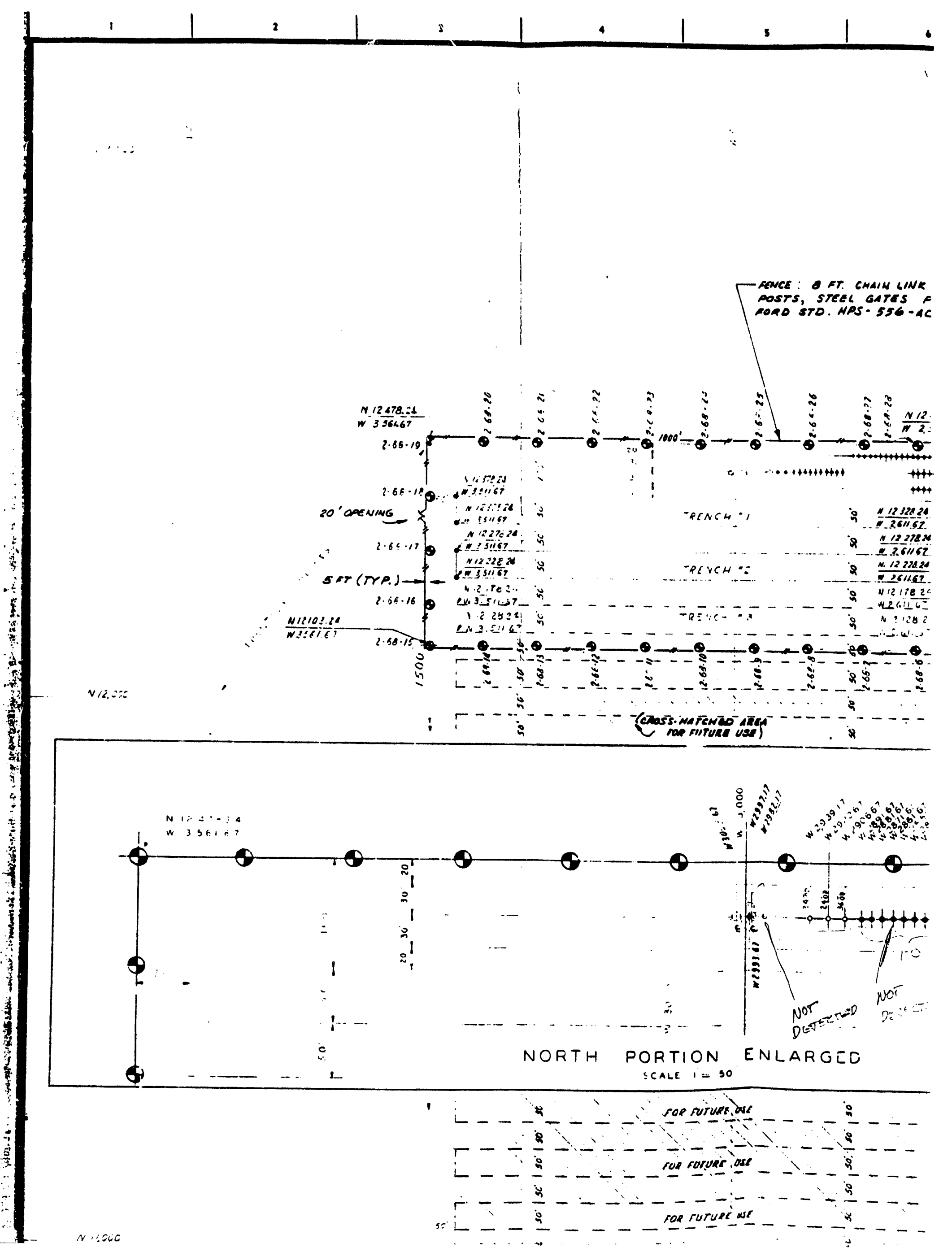




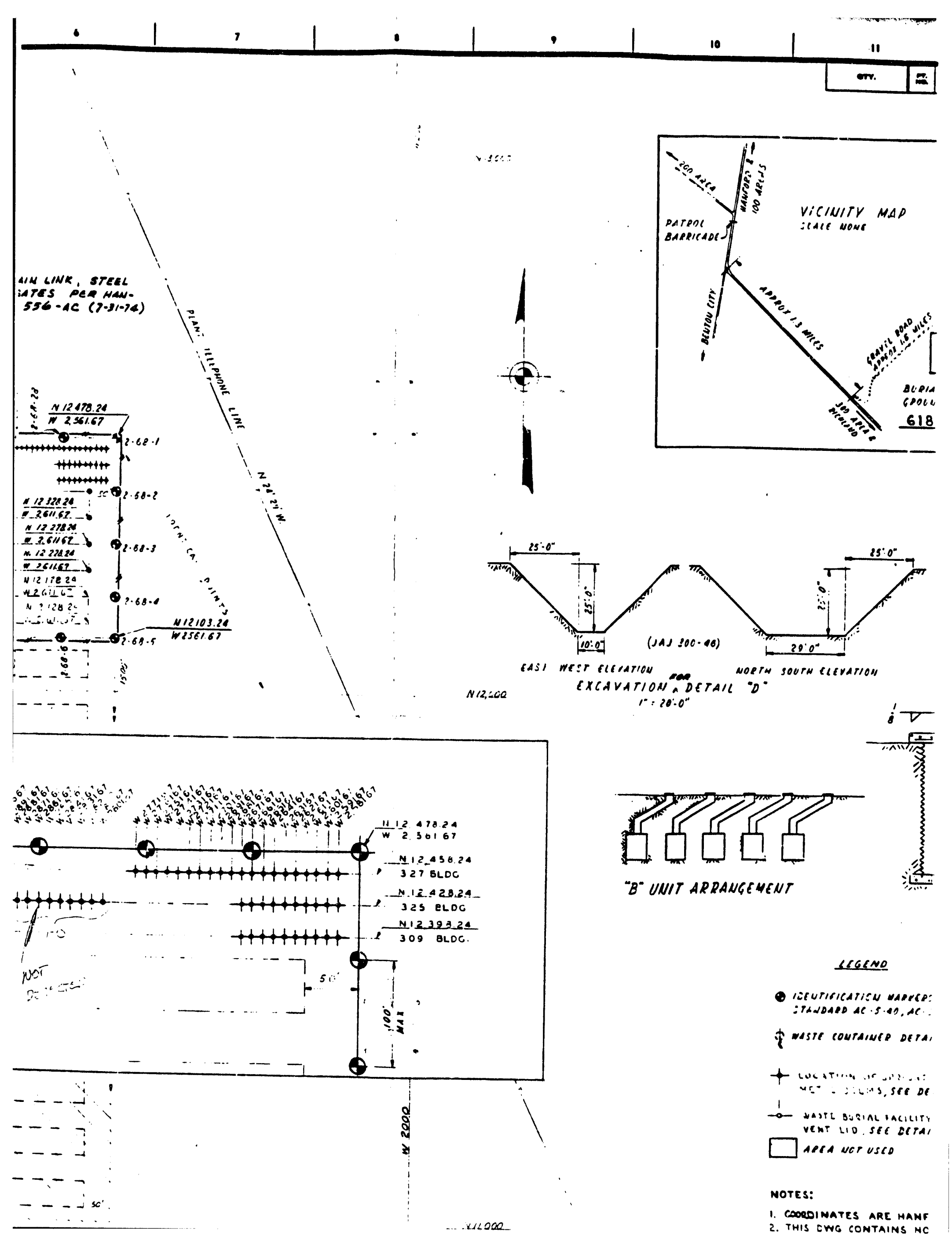




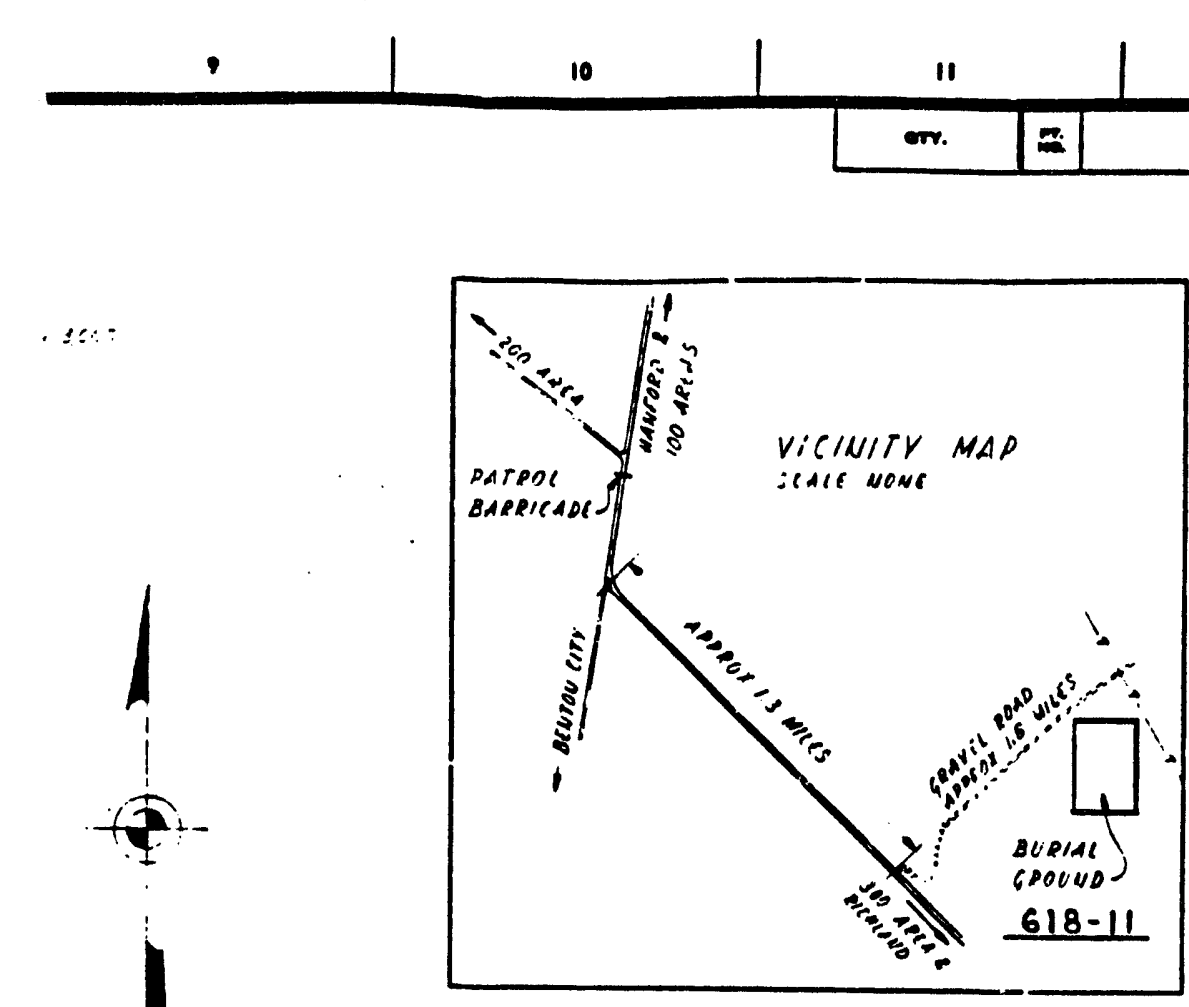

$12 \quad 18$

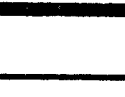

Dencons

A
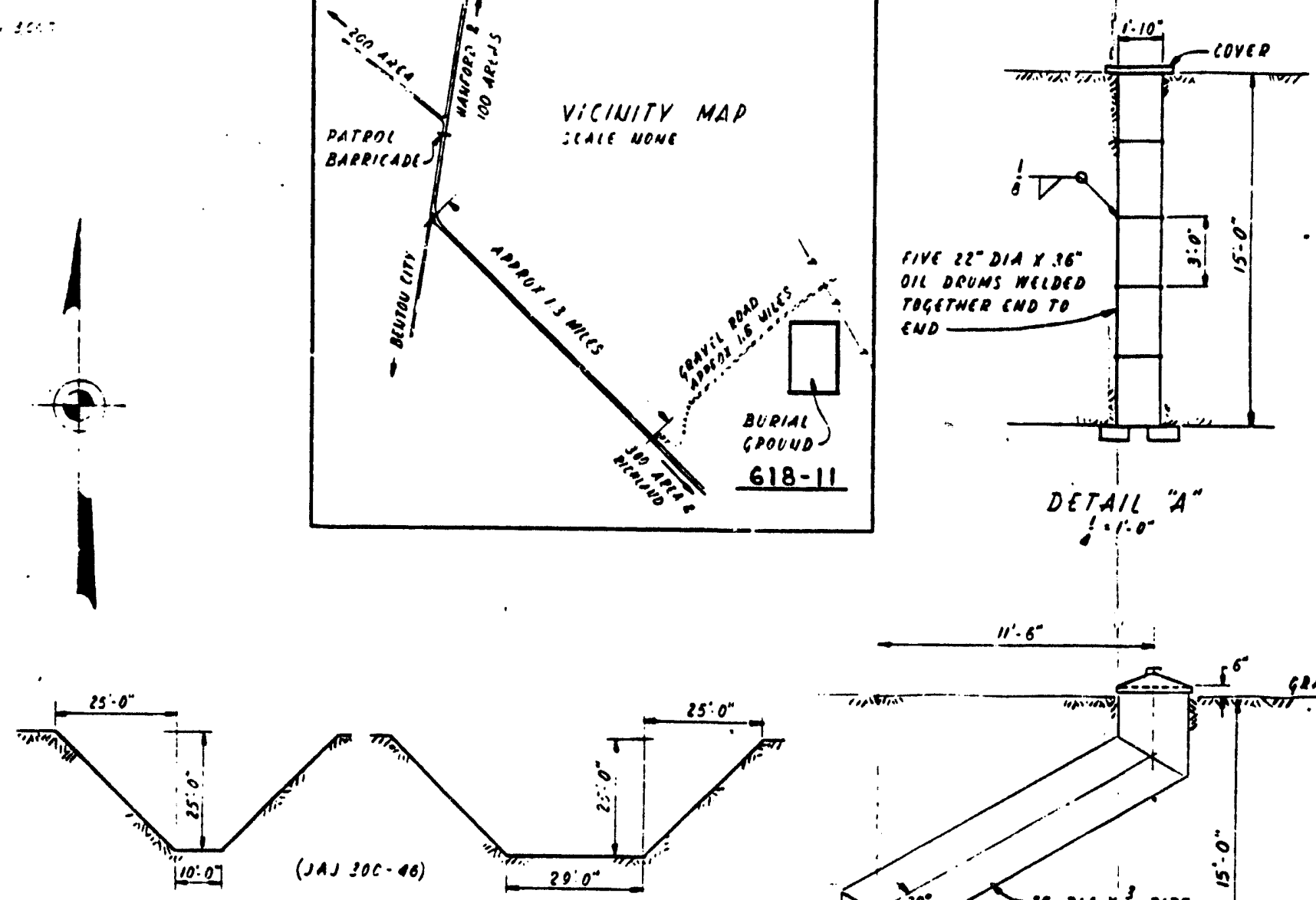

EASI WE:T ELECATIOU DOP NORTH SOUTW ELEVATION

ExCAVATION DETAIL "D.

$$
1 \times 20: 0 "
$$
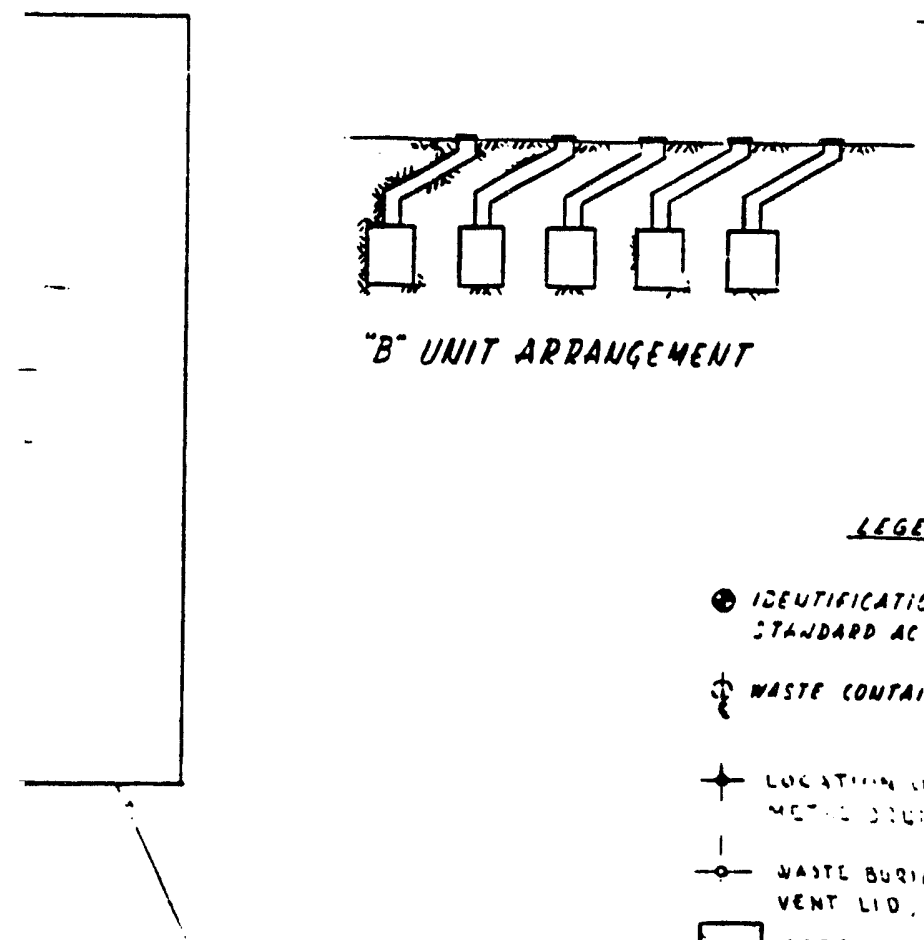

LCGLNO

- iefutification mareres as der nantord

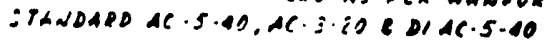

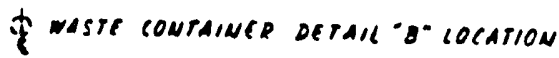

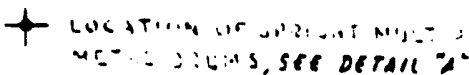

-o- masti buzinl iacility VENT HO, SEC DETAll" " LOCATION

apCA neT USCO

$H-6-930$

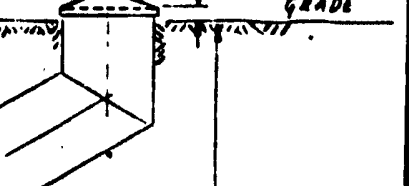
1 cone sicas 


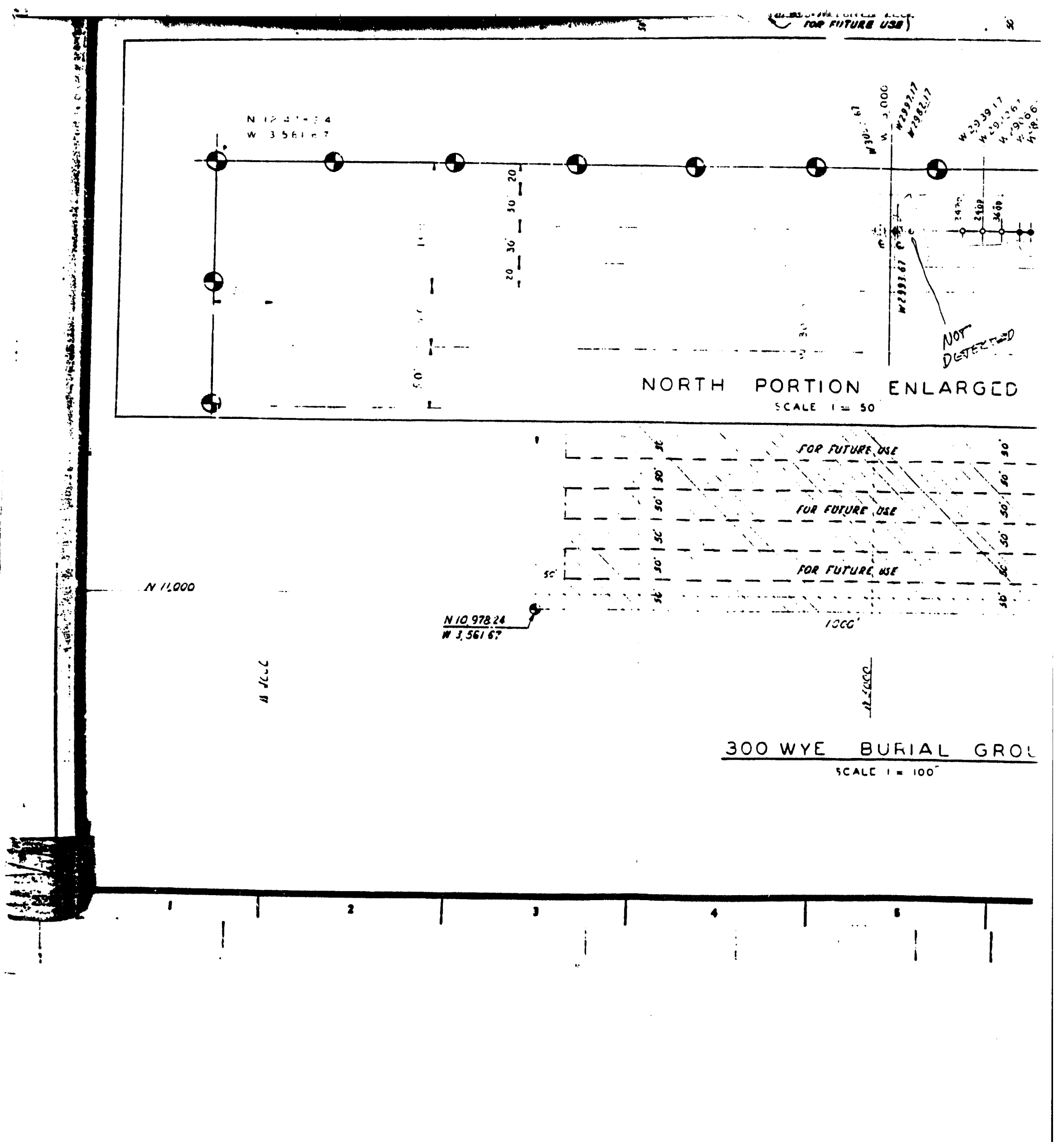


$\therefore$

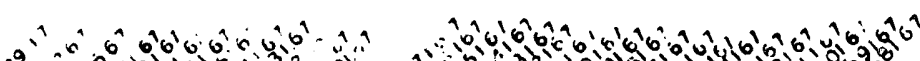

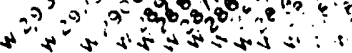

H.

111247024

$\theta$

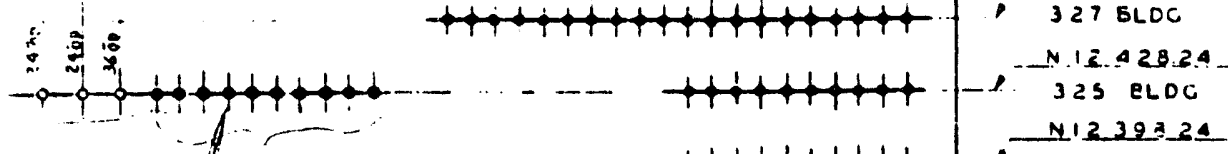
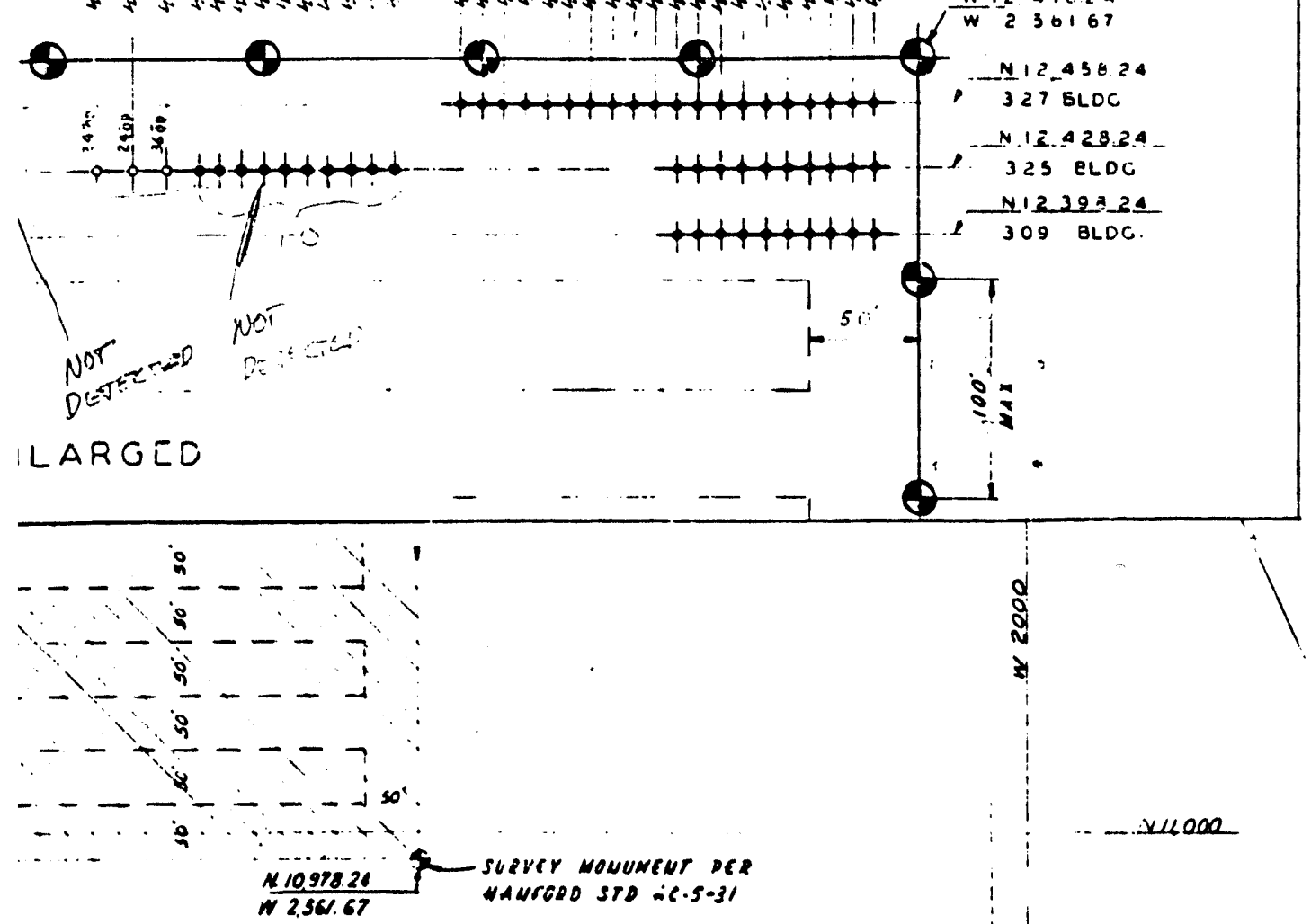

- . 14000

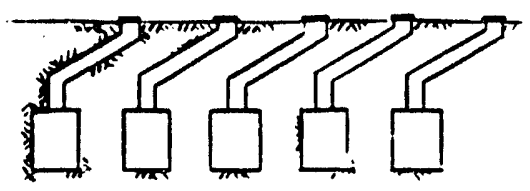

"B" UNIT ARRANGENENT

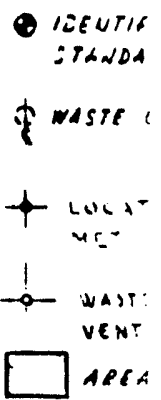

NOTES:

1. Coopoini

2. THIS on Requir

AS BUILT RECORO OWE NOT FOR FABRICATION

WAS FORMERLY H-3-9951

IAL GROUND $(618-11)$

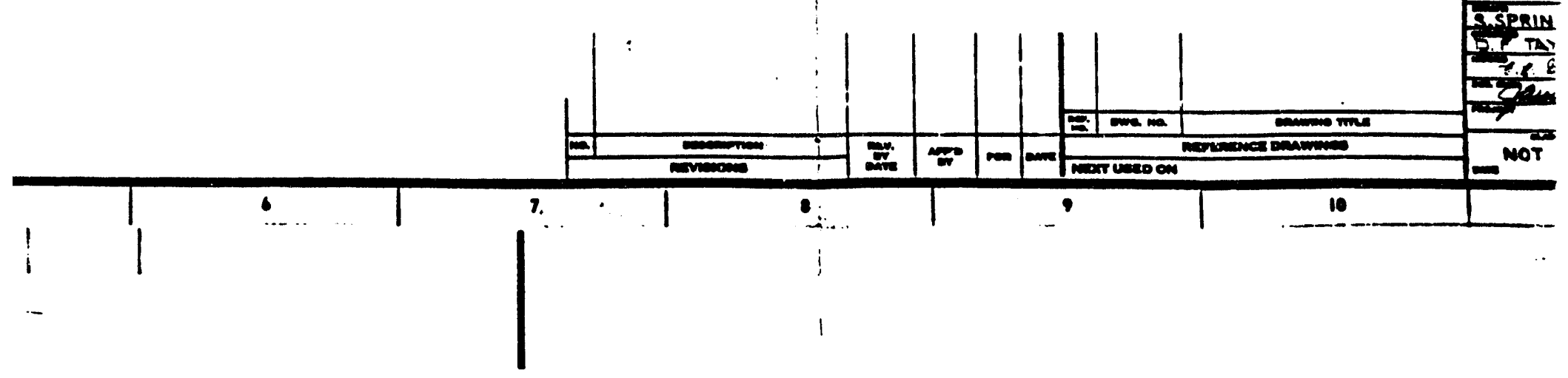




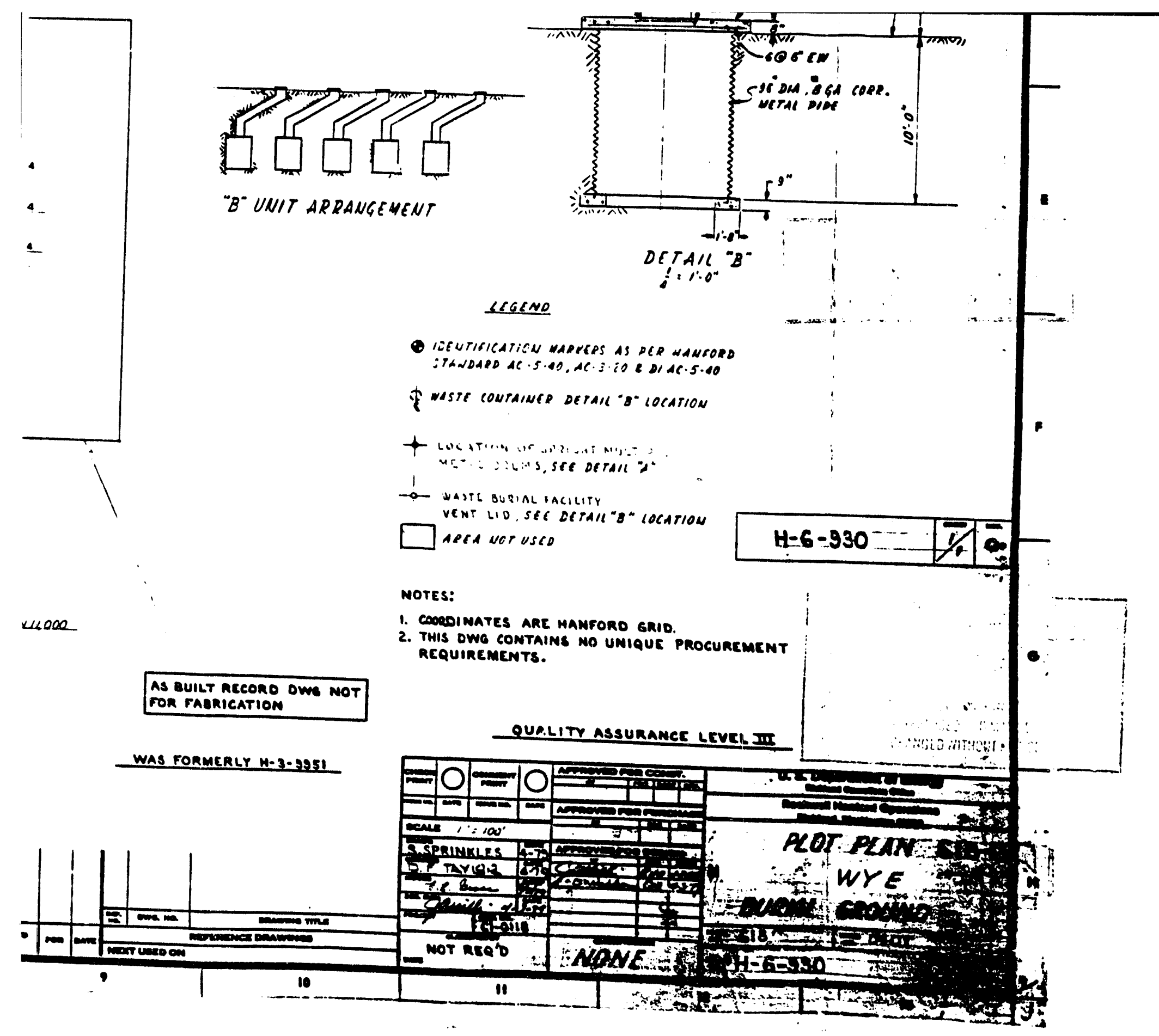



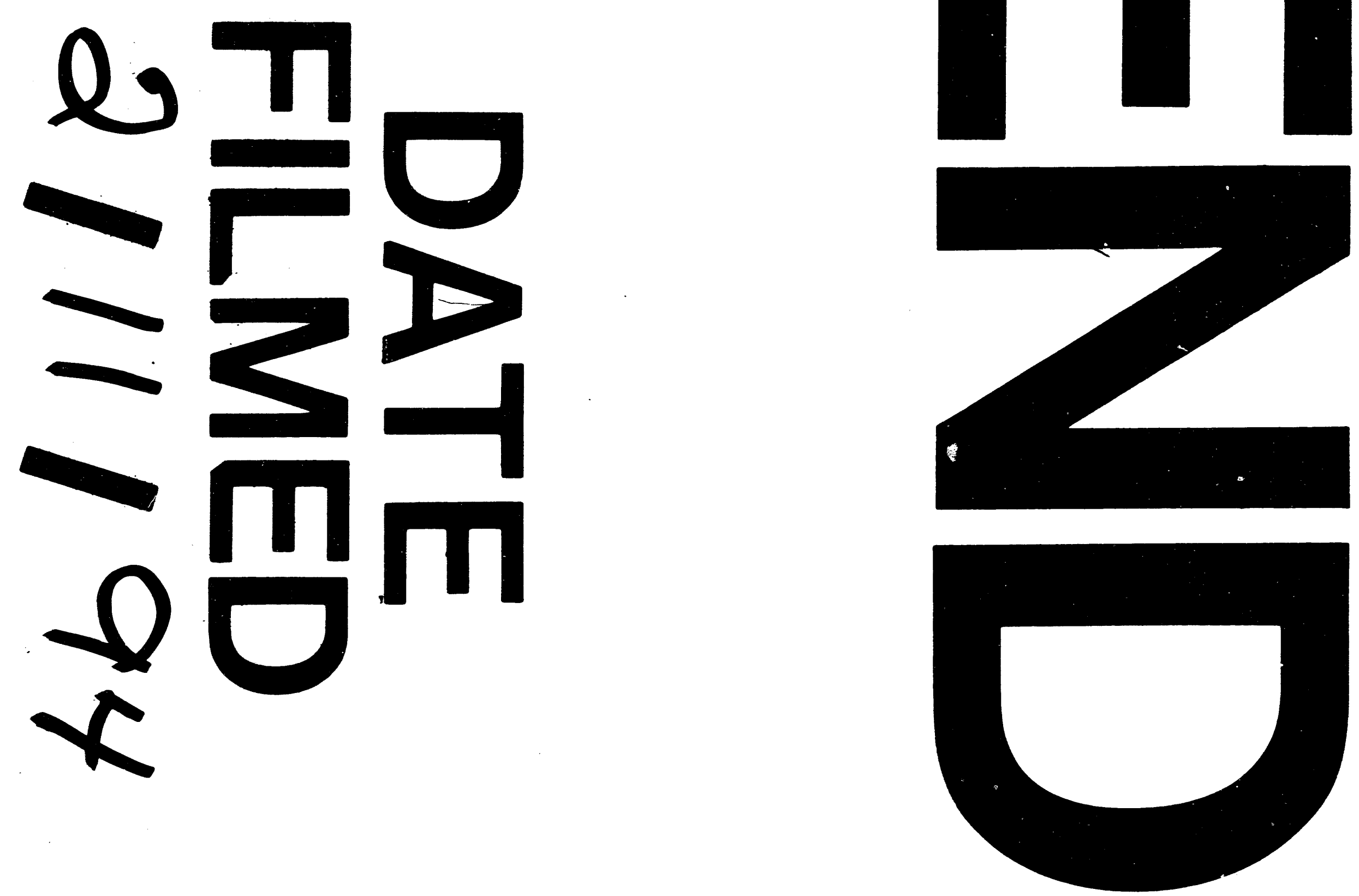
